\title{
Abandoned Seabird Eggs as a Calcium Source for Terrestrial Gastropods
}

\author{
Alexander L. Bond ${ }^{1,2}$ and Antony W. Diamond ${ }^{1}$ \\ ${ }^{1}$ Atlantic Cooperative Wildlife Ecology Research Network (ACWERN) and Department of Biology, University of New \\ Brunswick, P.O. Box 4400, Fredericton, New Brunswick E3B 5A3 \\ ${ }^{2}$ Current address: Department of Biology, Memorial University of Newfoundland, St. John's, Newfoundland and Labrador, \\ A1B 3X9 Canada; Corresponding author; e-mail: abond@mun.ca
}

Bond, Alexander L., and Antony W. Diamond 2007. Abandoned seabird eggs as a calcium source for terrestrial gastropods. Canadian Field-Naturalist 121(4): 433-435.

Birds' use of terrestrial gastropods to supplement calcium for egg formation has been well documented, but the reverse, gastropods using avian eggshells as a calcium source, has not been recorded previously. We collected Arctic Tern, Sterna paradisaea, eggs, abandoned in July 2006, that were found to have many terrestrial gastropods on the surface, and it appeared as though the outer eggshell layers were removed. Using scanning electron microscopy, we compared "grazed" and "ungrazed" sections of the same shell with eggshells collected in 2005 that were not attended by snails. It appears as though the snails removed the outer eggshell layers, presumably to supplement their own shell growth.

Keywords: Arctic Tern, Sterna paradisaea, White-lip Gardensnail, Cepaea hortensis, Glossy Pillar, Cionella lumbria, calcium, eggshell, New Brunswick

Although is it true that birds may seek to augment calcium intake during egg production (Nisbet 1997), particularly in acidified environments (Beintema et al. 1997; Brenninkmeijer et al. 1997; Mänd et al. 2000), the reverse relationship of snails exploiting an avian calcium source has not been recorded. This is likely because access by snails to avian calcium sources (i.e., eggs) is either limited during periods of nest attendance and incubation by adult birds, or because other avian calcium sources such as bones from dead chicks or eggshells ejected from the nest decompose or otherwise disappear from view.

Machias Seal Island (MSI; $44^{\circ} 30^{\prime} \mathrm{N}, 67^{\circ} 06^{\prime} \mathrm{W}$ ) is a 9.5 ha treeless island in the Bay of Fundy, Canada, and is home to several nesting seabird species, including Arctic Tern, Sterna paradisaea, and Common Tern, $S$. hirundo (Diamond and Devlin 2003; Bond et al. 2007). In the summer of 2006, the tern colony was abandoned on 25 June, before any eggs hatched. Although the proximate cause likely was intense predation on tern nests by Herring Gulls, Larus argentatus, and Great Black-backed Gulls, L. marinus (AWD unpublished data), the ultimate cause is likely a decrease in available food supply, mainly 0-group Atlantic Herring, Clupea harengus (DFO 2005), which preceded several years of near reproductive failure for both tern species (Bond et al. 2007).

On 22 July 2006, eleven tern eggs that had not been taken by gulls were collected and it was noticed that many small land snails had attached themselves to the exterior of the tern eggs, causing surface aberrations (Figure 1). Through visual comparison with eggs not attended by snails, we wanted to determine if snails were "grazing" on the tern eggs. Snails have been ob- served on abandoned eggs at tern colonies in southern New England (I. C. T. Nisbet, personal communication, 2006), but their effects on the eggs' exterior was not examined.

Our objective was to use electron microscopy to compare visually the surface of eggshells attended by snails with sections of the same eggshell that were unattended and with shells of eggs that had no snails present at all.

\section{Methods}

Tern eggs were collected on 22 July 2006 from Machias Seal Island, Bay of Fundy, Canada. Eggs were taken from nests located in the central vegetated portion of the island, where Canada Bluejoint, Calamagrostis canadensis, dominates and is kept short by regular mowing. Areas immediately surrounding the tern nests were not mowed to avoid damage to the nests' contents. Once the eggs were collected, snails were removed from the eggs. Eggs were wrapped individually in cellophane, frozen at $-18^{\circ} \mathrm{C}$ and transported to the University of New Brunswick, Fredericton, for analysis. Snails were similarly frozen in sterile polythene bags, and transported.

Eggshell samples were prepared and examined using a JEOL JSM 6400 scanning electron microscope with an operating voltage of $7 \mathrm{kV}$ at the Microscopy and Microanalysis Facility at the University of New Brunswick. Small sections of shell were mounted on aluminium stubs using carbon tape and carbon paste to properly ground the specimens, and sputter-coated with approximately $50 \mathrm{~nm}$ of gold. Photographs were taken at either $90^{\circ}$ (from directly above) or at $50^{\circ}$ to the electron beam. 


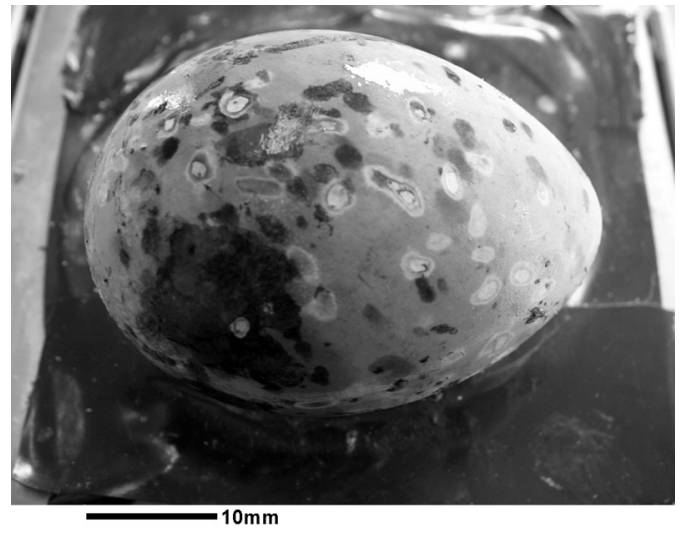

FIGURE 1. Abandoned Arctic Tern egg. Light circular marks on the shell's surface were the locations of snails.

\section{Results and Discussion}

Gastropods were identified at the New Brunswick Museum (Saint John, New Brunswick) as Cionella lumbria (Glossy Pillar; Stylommatophora: Cionellidae), a common terrestrial gastropod in the northeastern United States (Martin 2000), and immature or hatchling Cepaea hortensis (White-lip Gardensnail; Stylommatophora: Helicidae), which is common on several islands in the Bay of Fundy (D. McAlpine, New Brunswick Museum, St. John, personal communication, 2006).

Individual eggs had between 1 and 14 gastropods present (mean $\pm \mathrm{SD}, 4.18 \pm 3.79$ ), with Cepacaea hortensis being more common (40 of 46 total gastropods found on ten eggs), and the remainder being Cionella lumbria (6 of 46, present on three eggs). Linear regression found no relationship between snail abundance and egg size (breadth or length).

Areas on the tern eggshell that were "grazed" by the snails had the outer surface layer removed, exposing the radially oriented crystals immediately beneath the tangentially-oriented crystals that form the shells' surface (Becking 1975; Figure 2), whereas ungrazed areas (Figure 3 top) appeared similar to shells collected in 2005 (Figure 3 bottom). An examination of the interface of the grazed and non-grazed areas with the photograph taken at $50^{\circ}$ to the electron beam shows a "landscape" view, with the grazed areas lower than non-grazed areas (Figure 4), indicating the removal of the outer calcified layer of the eggshell by the snails. This outer crystalline layer varies in thickness from 1 to $10 \mathrm{~mm}$ in other bird species (Tyler 1964; Becking 1975), but it has not been examined previously in any of the Laridae.

It is unlikely that this method of calcium acquisition by snails would occur had the terns remained and incubated their nests through to hatching. Arctic Terns incubate their clutch of 1-3 eggs for approximately 21-23 days (Hatch 2002). Paquet (2001) found that

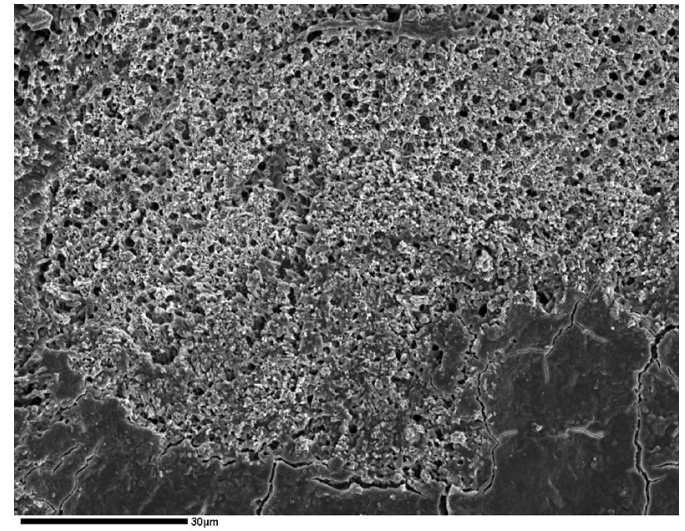

FIGURE 2. Grazed (top) and ungrazed areas (extreme bottom) of an Arctic Tern egg. Electron micrograph taken at $90^{\circ}$ to electron beam.

incubating terns spent $41 \%$ of their daily time budget incubating the egg, and that for more than $80 \%$ of the time, at least one adult in the pair was tending the eggs. This implies that any colonization attempt by gastropods would be unsuccessful because the egg would be unattended and accessible by the gastropods very little of the time. If such colonization did occur, the contact with the adult during incubation would likely remove the gastropod from the eggshell.

It is likely that the large number of abandoned eggs drew our attention to what could be a common phenomenon at the microscopic level. Seabirds can alter soil chemistry drastically (Mizutani et al. 1991), and it is likely that eggshells ejected from nests and bones from dead adults and chicks provide a reliable source of calcium enrichment, which could be accessed by the snails.

Rainfall on Machias Seal Island was well above average in 2006, with $469 \mathrm{~mm}$ between 15 May and $18 \mathrm{Au}-$ gust, compared with the mean ( \pm S.E.) of $225.0 \mathrm{~mm}$ $( \pm 29.2)$ over the previous 12 years (Bond et al. 2007), and this likely contributed to high productivity among the snails (Barrientos 2000; Tattersfield et al. 2001).

The gastropods' use of avian eggs as a calcium source is a reversal of the more typical relationship between birds and molluscs, as birds in acidified environments are often documented consuming molluscs to supplement production of calcium for their eggs (Beintema et al. 1997; Brenninkmeijer et al. 1997; Nisbet 1997; Mänd et al. 2000). It is our belief, though, that this behaviour in the snails is likely to be regular or frequent in occurrence, and that the snails are seeking new and abundant natural sources of calcium to promote shell growth, including abandoned eggs.

\section{Acknowledgments}

G. Bouchard and T. Clarke provided assistance in the field and A. Patterson provided transportation to and from the island. B. Bagley, G. Clark, P. Cranford, 

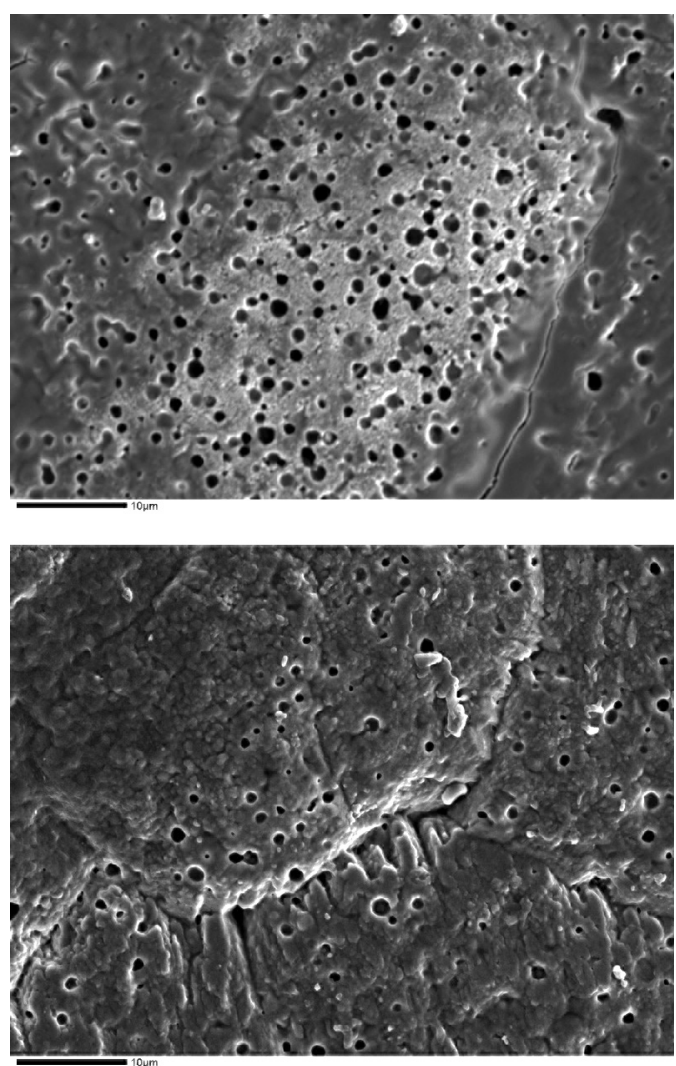

FIGURE 3. An ungrazed portion of the same shell as Figure 2 (above) and an Arctic Tern eggshell collected in 2005 with no snails observed (below). Electron micrographs taken at $90^{\circ}$ to electron beam.

R. Daley, R. Eldridge and R. Ross provided friendship and company on the island. D. F. McAlpine identified the snails, S. Belfry assisted with the SEM photography and S. Martin assisted in locating older references. K. C. Fraser, J. L. Lavers, A. J. Erskine and one anonymous reviewer provided helpful comments on previous drafts. The Atlantic Cooperative Wildlife Ecology Research Network funded this project. This is ACWERN publication number UNB-73.

\section{Literature Cited}

Barrientos, Z. 2000. Population dynamics and spatial distribution of the terrestrial snail Ovachlamys fulgens (Stylommatophora: Helicarionidae) in a tropical environment. Revista de Biología Tropical 48: 71-87.

Becking, J. H. 1975. The ultrastructure of the avian eggshell. Ibis 117: 143-151.

Beintema, A. J., T. Baarspul, and J. P. De Krijger. 1997. Calcium deficiency in Black Terns Chlidonias niger nesting on acid bogs. Ibis 139: 396-397.

Bond, A. L., M.-P. F. McNutt, T. C. Clarke, and A. W. Diamond. 2007. Machias Seal Island 1995-2006 Progress Report. Atlantic Cooperative Wildlife Ecology Research Network, Fredericton, New Brunswick.

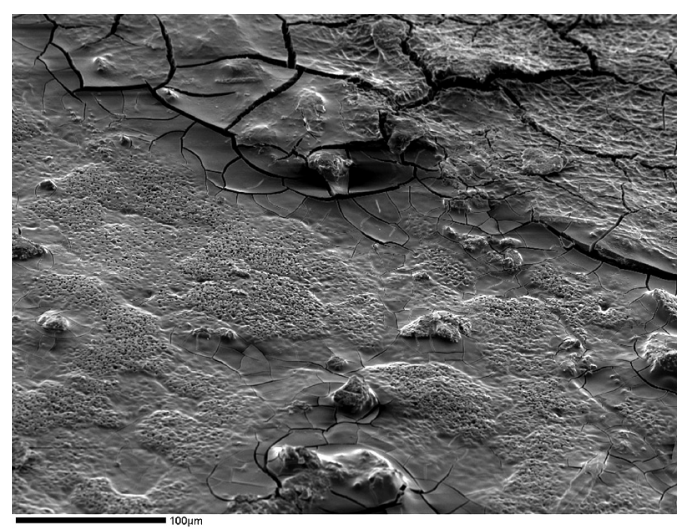

FIGURE 4. Arctic Tern eggshell showing grazed (bottom) and ungrazed (top) interface. Electron micrograph taken at $50^{\circ}$ to electron beam to provide a "landscape" view.

Brenninkmeijer, A., M. Klaassen, and E. W. M. Stienen. 1997. Sandwich Terns Sterna sandvicensis feeding on shell fractions. Ibis 139: 397-400.

DFO (Department of Fisheries and Oceans Canada). 2005. Stock Assessment Report on 4VWX Herring. Fisheries and Oceans Canada, Science Advisory Secretariat, Science Advisory Report 2005/033 (Revised).

Diamond, A. W., and C. M. Devlin. 2003. Seabirds as indicators of changes in marine ecosystems: ecological monitoring on Machias Seal Island. Environmental Monitoring and Assessment 88: 153-175.

Hatch, J. J. 2002. Arctic Tern (Sterna paradisaea). In The Birds of North America, (707). Edited by A. Poole and F. Gill. The Birds of North America, Inc., Philadelphia, Pennsylvania.

Mänd, R., V. Tilgar, and A. Leivits. 2000. Reproductive response of Great Tits, Parus major, in a naturally basepoor forest habitat to calcium supplementation. Canadian Journal of Zoology 78: 689-695

Martin, S. M. 2000. Terrestrial snails and slugs (Mollusca: Gastropoda) of Maine. Northeastern Naturalist 7: 33-88.

Mizutani, H., Y. Kabaya, P. J. Moors, and T. W. Speir. 1991. Nitrogen isotope ratios identify deserted seabird colonies. Auk 108: 960-964.

Nisbet, I. C. T. 1997. Female Common Terns Sterna hirundo eating mollusc shells: evidence for calcium deficits during egg laying. Ibis 139: 400-401.

Paquet, J. M. 2001. Time-budget flexibility of breeding Arctic Terns (Sterna paradisaea): an investigation of the behavioural buffer. M.Sc. thesis, University of New Brunswick, Fredericton, New Brunswick.

Tattersfield, P., C. M. Warui, M. B. Seddon, and J. W. Kiringe. 2001. Land-snail fauna of afromontane forests of Mount Kenya, Kenya: ecology, diversity and distribution patterns. Journal of Biogeography 28: 843-861.

Tyler, C. 1964. A study of the egg shells of the Anatidae. Proceedings of the Zoological Society of London 142: 547-583.

Received 9 March 2007

Accepted 26 August 2008 